Annals of Warsaw University of Life Sciences - SGGW

Land Reclamation No 48 (4), 2016: 329-340

(Ann. Warsaw Univ. Life Sci. - SGGW, Land Reclam. 48 (4), 2016)

\title{
The estimation of some wild flowers seed material from the natural-valuable meadow habitats
}

\author{
MARIA JANICKA ${ }^{1}$, BOGUMIŁA PAWLUŚKIEWICZ ${ }^{2}$, \\ ELŻBIETA MAŁUSZYŃSKA ${ }^{3}$, ANNA SZYDŁOWSKA ${ }^{3}$ \\ ${ }^{1}$ Department of Agronomy, ${ }^{2}$ Department of Environmental Improvement \\ Warsaw University of Life Sciences - SGGW \\ ${ }^{3}$ Department of Seed Science and Technology, Plant Breeding and Acclimatization Institute - National \\ Research Institute in Radzików
}

\begin{abstract}
The estimation of some wild flowers seed material from the natural-valuable meadow habitats. The restoration of the species composition of the meadow habitats is often linked to the introduction of the typical species' seeds. The effectiveness of that treatment requires getting the acquired detailed knowledge of the germination biology of peculiar species. Eight typical plant species of four non-forest habitats of the river valleys, representing the following types: Cnidion dubii (6440), Molinion (6410), Arrhenatherion (6510) and Festuco-Brometea (6210) were investigated. The diasporas were collected in the years 2014-2015 on the meadows of PLH 140016 protection area near Mniszew (Kozienice county, Mazovian voivodeship). The ability of seeds' germination in the laboratory conditions was studied. It was stated that Cnidion and Molinion meadows' species require pre-chilling to break the seeds' dormancy, while the Arrhenatherion meadows and xerotermophilous swards do not require such treatment. The Allium angulosum, Plantago lanceolata, Achillea millefolium and Eryngium planum were characterized by high vigour and germination capability as well as the low share of dead seeds. The extremely drought in 2015 caused the decreasing in germination capability and increasing in the dead seeds' share. The preliminary studies, presented in this paper, show that Cnidion and Molinion meadows may be most difficult to restore because of the necessity of breaking the seeds' dormancy and higher sensitiveness for the unfavourable weather condi-
\end{abstract}

tions during the seed ripening stage. The studies have practical significance for the works connected with the floristic diversity' increasing of threatened communities and the restoration of the destroyed meadow habitats.

Key words: restoration of meadow communities, wild flowers, germination capacity, fresh ungerminated seeds, dead seeds

\section{INTRODUCTION}

The monitoring of natural meadow habitats in continental bio-geographical area of Poland showed that only $20 \%$ of the habitats characterized themselves by the proper protection state (GIOŚ 2012). The obligatory legal system obliges the entities, which activities pose the direct thread for the environment to take actions in favour of prevention of biological diversity loss and remediation of ensuing damages (Directive on the conservation of natural habitats... 1992, Directive on the conservation of wild birds 2009, The EU Biodivesity Strategy to 2010, Directive on environmental liability... 2013). 
The restoration of the species composition of the meadow community in the natural habitats, where the lack of diasporas of meadow plants in the soil may be found, requires the introduction of the characteristic species' seeds (Janicka 2015). The importance of seed propagation of native ecotypes has now increased, to provide seed for restoration and re-establishment of the most important types of semi-natural grassland in central Europe (Scotton et al. 2012). A problem is that the seed quality of selected wild flowers is broadly undetermined, especially with reference to the ones from local provenance (Haslgrübler et al. 2013). It is assumed that in our geographical region about $70 \%$ of the natural flora species produce dormant seeds, which are unable to germinate in the moment of dispersal (Projekt FlorNatur ROBiA 2014). The seeds of that kind are being produced by many species of meadow habitats, for example Cnidion and Molinion meadows (Hölzel and Otte 2004, Krautzer et al. 2013). The effectiveness of species introducing requires the aquiration of knowledge about the conditions of necessary for seeds' germination. The ecological, anatomical and physiological mechanisms of dormancy may be very various (Baskin and Baskin 2004), since the precise knowledge about the germination biology of the typical wild flowers of endangered grassland communities is important.

The aim of the work was the estimation of the conditions of germination ability estimation and the analyse of the germination capacity of the seeds of eight natural flora species of four natural habitats, protected by the Habitats Directive, occuring in big river valleys; either the estimation of the weather conditions influence on the seeding material value.

\section{MATERIAL AND METHODS}

Eight plant species of four non-forest natural habitats, occurring in the river valleys - Cnidion dubii $(6,440)$, Molinion (6410), Arrhenatherion (6510) and Festuco-Brometea (6210) were studied. Two of studied species - Cnidium dubium and Allium angulosum are on the Polish Red List of Endangered Plant Species, classified as vulnerable - V (Zarzycki and Szeląg 2006). Either Allium angulosum became partially protected in 2014 (Dz.U. 2014, poz. 1409).

The diasporas (seeds, fruits) were collected on the meadows of Special Area of Conservation (SAC) of the Lower Pilica River Valley (PLH 140016) area in Mazovian voivodeship, Kozienice county, Magnuszew commune, near

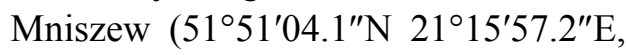
$\left.51^{\circ} 50^{\prime} 00.3^{\prime \prime} \mathrm{N} 21^{\circ} 17^{\prime} 05.2^{\prime \prime} \mathrm{E}\right)$. The following species diasporas were taken from the close-to-river flood terrace: $\mathrm{Al}$ lium angulosum, Cnidium dubium, Galium boreale, Sanquisorba officinalis and from the more far off sites - Achillea millefolium and Plantago lanceolata. Eryngium planum and Scabiosa ochroleuca were taken from sandy alluviums and the areas of low cohesion. 
The seed material was taken by hand, in the third decade of September 2014 and 2015. The Vinczeffy hydrothermic index characterises the 2014 growing season as dry $\left(0.132 \mathrm{~mm} \cdot{ }^{\circ} \mathrm{C}^{-1}\right)$. In that period June was colder than usually, but July and September - warmer. The weather conditions noted in June and July were generally favourable for the plants' growth and development (GUS 2015). The seed ripening stage went in favourable weather conditions. Warm, sunny and dry weather in September assured good conditions for seeds collection. The vegetation period in 2015 was characterised by deep drought due to long rainless periods and turned out to be extremely dry (the Vinczeffy hydrothermic index lower than $0.1 \mathrm{~mm} \cdot{ }^{\circ} \mathrm{C}^{-1}$ ). Early on April in the more dry habitats the drying of the outer soil layer were noted, as the result of the lack of the rainfalls that state deepened in May and June (GUS 2016). The lowest precipitation were noted in August (only $11 \mathrm{~mm}$ ), furthermore in that month the exceptionally high air temperatures came out (the mean average one equal to $23^{\circ} \mathrm{C}$ ). The weak plant growth, weak earing, early ripening and insufficient forming and fulfilling of the seeds (for example the small-seeded papilonaceous' yields were $27 \%$ lower than in 2014 (GUS 2016).

For each species, ripe seeds were taken from at least two populations of a minimum 10 individuals of a single large population and mix them. After cleaning (separation of the fully developed seeds from empty seed coats, in- fected seeds and the rest of the pericarp; by hand and using the laboratory sieves) the seeds were kept in paper bags under dry conditions in the temperature of $15^{\circ} \mathrm{C}$ by 5 months, when the initial viability tests were started.

Within the studies the analysis of the germination in laboratory conditions was carried out. For the estimation of the laboratory germination conditions seeds were sown (at 25 ones) in the plastic paint trays, spread out with the filtration blotting paper, moistened to $60 \%$ of water capacity and kept in two variants:

- Variant 1 (V1) - "without pre-chilling" - the seeds were put in the thermostat of constant temperature $20^{\circ} \mathrm{C}$ and constant lightning with white, cold light (750 to $1,250 \mathrm{~lx}$ ). The estimation of the germination was made after 14 days;

- Variant 2 (V2) - "with pre-chilling" - the seeds were put on moisten blotting paper, in the temperature $7^{\circ} \mathrm{C}$ for 35 days in the darkness for breaking dormancy and then in the thermostat in variable temperature $-20^{\circ} \mathrm{C}$ for $16 \mathrm{~h}$ in the darkness and $30^{\circ} \mathrm{C}$ for $8 \mathrm{~h}$ with the light ( 750 to $1,250 \mathrm{~lx}$ ). The estimation of seed germination was made after 7 days.

In both variants as germinated seeds the ones with the emergence of the ridicule (physiological germination) were treated.

The appropriate evaluation of the germination capacity was carried out as follow: the seeds (50 in each of three repetitions) were sown on moistened 
blotting paper and put in the thermostat in variable temperature $-20^{\circ} \mathrm{C}$ for $16 \mathrm{~h}$ (darkness) and $30^{\circ} \mathrm{C}$ for $8 \mathrm{~h}$ with the light (750 to $1,250 \mathrm{~lx})$. Cnidium dubium and Allium angulosum seeds were put in the thermostat after previous pre-chilling for 28 days (temperature $7^{\circ} \mathrm{C}$, darkness) in 2015 and for 7 days in 2016 due to strong seeds' infection observed in the previous year. In 2016 also the Sanguisorba officinalis seeds were chilled for 7 days.

The vigour (first counting, previously named the energy of germination) and the germination capacity (last counting) of the seeds were phrased in per cents as the share of the normal seedlings in certain period for peculiar species or genus (Table 1). The dates of the germination capability were determined on the base of various sources for peculiar genus of the plants, due to lack of the data for investigated species (Ellis et al. 1985, ISTA 2015).
The analyse of germination capacity was carried out according to the International Rules of Seeds Evaluation (ISTA 2015), with the separation to normal seedlings (showing all the structural elements of the plant of peculiar species), abnormal seedlings (not showing all the structural elements of the plant of peculiar species, e.g. without properly developed root), dead seeds (not germinated but with a soft seed coat and/or strongly infected by fungi) and fresh ungerminated seeds (not germinated and not infected by fungi), in other words dormant seeds.

The results of the first counting (the germination energy), germination capacity, dead and fresh ungerminated seeds' shares were statistically analysed with the help of Stagraphics Plus programme. The variability of the analysed traits was estimated with the help of the variability coefficient, counted on the base of standard deviation for non-convicted characteristics and mean averages. To determine the significance between the

TABLE 1. The investigated meadow plant species and the dates of germination capability estimations

\begin{tabular}{|l|l|c|c|}
\hline \multirow{2}{*}{ Species* } & \multicolumn{1}{|c|}{ Community } & $\begin{array}{c}\text { Number of days } \\
\text { to the first } \\
\text { counting }\end{array}$ & $\begin{array}{c}\text { to the last } \\
\text { counting }\end{array}$ \\
\hline $\begin{array}{l}\text { Cnidium dubium (Schkuhr) Thell. } \\
\text { Allium angulosum L. }\end{array}$ & Cnidion dubii $(6440)$ & 14 & $63^{* *}$ \\
\hline Sanguisorba officinalis L. & Molinion caeruleae & 7 & $63 * *$ \\
Galium boreale L. & $(6410)$ & 5 & 28 \\
\hline Achillea millefolium L. & Arrhenatherion & 10 & 14 \\
Plantago lanceolata L. & elatioris (6510) & 5 & 42 \\
\hline Eryngium planum L. & Festuco-Brometea $(6210)$ & 7 & 14 \\
Scabiosa ochroleuca L. & & 7 & 35 \\
\hline
\end{tabular}

* Nomenclature of species according to Mirek et al. (1995); ** in 2015 the analyse was finished earlier (C. dubium after 42, and A. angulosum after 21days) because of the high share of dead seeds. 
pairs of the mean averages the one- and two-factors analyses (Anova) was used. The relevance level of 0.05 was accepted. The Tuckey test was used to compare the mean averages. To determine the similarity level between the species of similar features of the seed material (the germination capacity, dead and fresh ungerminated seeds and abnormal seedlings shares) the hierarchic analyse of aggregation (the Ward method) was made, with the use of the Euclidean distance square.

\section{RESULTS AND DISCUSSION}

Analysis of the conditions for the determination of the germination capac-

ity. The authors' studies results shown that Allium angulosum and Cnidium dubium (the Cnidion meadows' species) have the dormant seeds (Table 2). It is compatible with the studies of Puchalski et al. (2014) that in the case of rare, endangered plants found that most peatland and wet sites' species produce dormant or partly dormant seeds. Breaking of their dormancy required pre-chilling and variable temperature for germination. Likewise in the studies of Hölzel and Otte (2004) primary conditional dormancy disappeared in most cases after a period of cold wet stratification of flood-meadow species seeds of the alliance Cnidion. During the authors' own experiments in germination conditions V2 Allium angulosum germinated better (56\%) than Cnidium dubium (16\%). In the references it may be found that the Allium genera seeds, frozen before sowing, germinated in the temperature $10-15^{\circ} \mathrm{C}$ during 14 days (Specht and Keller 1997).

The species of the Molinion meadows germinated poorly after pre-chilling as well as without one. In the studies of Krautzer et al. (2013) pre-chilling of seed material harvested from Molinion meadows (but without reference to peculiar species) caused a significant increase in germination capacity of the seed material. Other authors, such as ISTA (2015) and Elis et al. (1985) did not proved the necessity of chilling for

TABLE 2. Preliminary assessment of germination capacity in two variants of conditions (\%)

\begin{tabular}{|c|c|c|c|}
\hline \multirow[b]{2}{*}{ Species } & \multirow[b]{2}{*}{ Community } & \multicolumn{2}{|c|}{ Variant } \\
\hline & & $\begin{array}{c}\text { "without } \\
\text { pre-chilling" (V1) }\end{array}$ & $\begin{array}{c}\text { „with } \\
\text { pre-chilling” (V2) }\end{array}$ \\
\hline $\begin{array}{l}\text { Cnidium dubium (Schkuhr) Thell. } \\
\text { Allium angulosum L. }\end{array}$ & Cnidion dubii & $\begin{array}{l}0 \\
0\end{array}$ & $\begin{array}{l}16 \\
56\end{array}$ \\
\hline $\begin{array}{l}\text { Sanguisorba officinalis L. } \\
\text { Galium boreale L. }\end{array}$ & Molinion caeruleae & $\begin{array}{c}24 \\
0\end{array}$ & $\begin{array}{c}4 \\
32 \\
\end{array}$ \\
\hline $\begin{array}{l}\text { Achillea millefolium } \mathrm{L} . \\
\text { Plantago lanceolata } \mathrm{L} .\end{array}$ & Arrhenatherion elatioris & $\begin{array}{l}80 \\
12\end{array}$ & $\begin{array}{l}64 \\
56\end{array}$ \\
\hline $\begin{array}{l}\text { Eryngium planum L. } \\
\text { Scabiosa ochroleuca L. }\end{array}$ & Festuco-Brometea & $\begin{array}{l}62 \\
52 \\
\end{array}$ & $\begin{array}{l}44 \\
32 \\
\end{array}$ \\
\hline
\end{tabular}


breaking the dormancy period of the seeds of Sanguisorba officinalis and Galium boreale.

The seeds of Arrhenatherion meadows and xerothermophilous swards (FestucoBrometea) germinated well without prechilling (except Plantago lanceolata), what indicates that they do nor demand that treatment for breaking the dormancy. Similarly, in the study of Haslgrübler et al. (2011) the germination capacity of the pre-chilled seed material, harvested from an Arrheratherion meadow, was lower than without pre-chilling.

The analyse of seed germination. The value of the seed material of the wild flowers was determined mainly by the germination capacity and dead seeds' share, modified by the weather conditions. From the restoration of plant communities' point of view the vigour of the seeds (in the form of germination energy) is also important because of higher competiveness of the young plants in the early period of the growth and development. The significant differences between the species in the values of peculiar parameters of seed material evaluation were noted.

The best vigour (first counting) was characterised for the Arrhenatherion meadows species' seeds, as follows: Achillea millefolium, Plantago lanceolata and Eryngium planum (above 55\%), but the worst one for: Galium boreale and Cnidium dubium (below 10\%) (Table 3). The vigour of the seeds collected in 2015 was significantly lower than collected in 2014 only in the case of four species, $30-40 \%$ on average for: $\mathrm{Al}$ lium angulosum, Eryngium planum and Achillea millefolium, but four-times in the case of Cnidium dubium. It may be assumed that the basic reason was the high temperature during seed development and ripening.

The weather conditions in the years of the studies highly influenced the ger-

TABLE 3. Analysis of the first counting (\%)

\begin{tabular}{|c|c|c|c|c|c|c|}
\hline \multirow[b]{2}{*}{ Species (S) } & \multicolumn{3}{|c|}{ Year of harvest (Y) } & \multicolumn{3}{|c|}{ Coefficient of variation } \\
\hline & 2014 & 2015 & $\begin{array}{l}L S D_{0.05} \\
(\text { for Y) }\end{array}$ & Mean (S) & 2014 & 2015 \\
\hline $\begin{array}{l}\text { Cnidium dubium (Schkuhr) Thell } \\
\text { Allium angulosum L. }\end{array}$ & $\begin{array}{c}13 \mathrm{ab} \\
60 \mathrm{c}\end{array}$ & $\begin{array}{c}3 \mathrm{a} \\
36 \mathrm{~b}\end{array}$ & $\begin{array}{c}7.6 \\
16.0\end{array}$ & $\begin{array}{l}8.0 \mathrm{ab} \\
48.0 \mathrm{~cd}\end{array}$ & $\begin{array}{c}34.6 \\
6.7 \\
\end{array}$ & $\begin{array}{l}43.3 \\
25.5 \\
\end{array}$ \\
\hline $\begin{array}{l}\text { Sanguisorba officinalis } \mathrm{L} . \\
\text { Galium boreale L. }\end{array}$ & $\begin{array}{l}0 \mathrm{a} \\
5 \mathrm{a}\end{array}$ & $\begin{array}{c}37 \mathrm{~b} \\
0 \mathrm{a}\end{array}$ & $\begin{array}{l}9.8 \\
9.8\end{array}$ & $\begin{array}{c}18.3 \mathrm{ab} \\
2.7 \mathrm{a}\end{array}$ & $\begin{array}{c}- \\
114.6\end{array}$ & $\begin{array}{c}16.7 \\
-\end{array}$ \\
\hline $\begin{array}{l}\text { Achillea millefolium } \mathrm{L} . \\
\text { Plantago lanceolata } \mathrm{L} .\end{array}$ & $\begin{array}{l}83 \mathrm{~d} \\
53 \mathrm{c}\end{array}$ & $\begin{array}{c}58 \mathrm{~cd} \\
68 \mathrm{~d}\end{array}$ & $\begin{array}{l}15.8 \\
16.4\end{array}$ & $\begin{array}{l}70.3 \mathrm{~d} \\
60.7 \mathrm{~d}\end{array}$ & $\begin{array}{l}11.2 \\
15.6\end{array}$ & $\begin{array}{l}6.0 \\
8.8\end{array}$ \\
\hline $\begin{array}{l}\text { Eryngium planum } \mathrm{L} . \\
\text { Scabiosa ochroleuca } \mathrm{L} .\end{array}$ & $\begin{array}{l}69 \mathrm{~cd} \\
28 \mathrm{~b}\end{array}$ & $\begin{array}{c}42 \mathrm{bc} \\
31 \mathrm{~b}\end{array}$ & $\begin{array}{l}17.4 \\
13.3\end{array}$ & $\begin{array}{c}55.7 \mathrm{~d} \\
29.7 \mathrm{bc}\end{array}$ & $\begin{array}{c}14.5 \\
0.0\end{array}$ & $\begin{array}{c}9.5 \\
26.6\end{array}$ \\
\hline$L S D_{0.05}($ for $\mathrm{S})$ & 18.2 & 16.0 & - & 23.6 & - & - \\
\hline Mean $(\mathrm{Y})$ & 39.0 & 34.3 & - & - & - & - \\
\hline$L S D_{0.05}(\mathrm{Y})$ & \multicolumn{2}{|c|}{7.5} & - & - & - & - \\
\hline
\end{tabular}

\footnotetext{
* Homogenous groups in columns.
} 
mination capacity (last counting) (Table 4). In 2014 the average germination capacity for the species was high and equal to $61 \%$ (11-65\%), but in 2015 it was lower in average of $24 \%$ and more tion period was typical for the seeds of Scabiosa ochroleuca and Galium boreale.

- The lowest germination capacity (20-30\% on average) was typical for

TABLE 4. Analysis of the germination capacity (\%)

\begin{tabular}{|c|c|c|c|c|c|c|}
\hline \multirow{2}{*}{ Species (S) } & \multicolumn{4}{|c|}{ Year of harvest $(\mathrm{Y})$} & \multicolumn{2}{|c|}{$\begin{array}{l}\text { Coefficient of } \\
\text { variation }\end{array}$} \\
\hline & 2014 & 2015 & $\begin{array}{l}L S D_{0.05} \\
\text { (for Y) }\end{array}$ & Mean $(S)$ & 2014 & 2015 \\
\hline Cnidium dubium (Schkuhr) Thell & $37 \mathrm{ab}^{*}$ & $3 a$ & 22.7 & $20.0 \mathrm{a}$ & 37.6 & 47.8 \\
\hline Allium angulosum $\mathrm{L}$. & $80 \mathrm{~cd}$ & $74 d$ & 19.5 & $77.0 \mathrm{c}$ & 15.0 & 2.7 \\
\hline Sanguisorba officinalis L. & $11 \mathrm{a}$ & $49 \mathrm{bc}$ & 16.2 & $30.0 \mathrm{a}$ & 57.4 & 16.4 \\
\hline Galium boreale L. & $52 \mathrm{bc}$ & $34 b$ & 27.0 & $43.0 \mathrm{ab}$ & 27.7 & 25.6 \\
\hline Achillea millefolium $\mathrm{L}$. & $85 \mathrm{~d}$ & $59 \mathrm{~cd}$ & 15.6 & $72.0 \mathrm{c}$ & 9.7 & 8.5 \\
\hline Plantago lanceolata L. & $76 \mathrm{~cd}$ & $69 \mathrm{~d}$ & 15.8 & $72.5 \mathrm{c}$ & 9.1 & 10.1 \\
\hline Eryngium planum L. & $95 d$ & $48 \mathrm{bc}$ & 9.2 & $71.5 \mathrm{bc}$ & 4.8 & 7.2 \\
\hline Scabiosa ochroleuca L. & $52 \mathrm{bc}$ & $35 b$ & 19.8 & $43.5 \mathrm{ab}$ & 15.3 & 27.3 \\
\hline$L S D_{0.05}$ (for $\left.\mathrm{S}\right)$ & 28.2 & 18.0 & - & 28.1 & - & - \\
\hline Mean $(Y)$ & 61.0 & 46.4 & - & - & - & - \\
\hline$L S D_{0.05}(\mathrm{Y})$ & \multicolumn{2}{|c|}{8.9} & - & - & - & - \\
\hline
\end{tabular}

* Homogenous groups in columns.

differentiated (3-74\%). The three species groups of different germination capacity were singled out:

- The high germination capacity (71$-77 \%$ on average in the study period) was characterized for the seeds of: Allium angulosum, Plantago lanceolata, Achillea millefolium and Eryngium planum. For two first species the parameter was not significantly influenced by the weather conditions, but for two others the values of germination capacity of the seeds from 2015 were significantly lower than from 2014, adequately 35 and $50 \%$.

- The germination capacity on average level of $43 \%$ during the investiga- the seeds of Sanguisorba officinalis and Cnidium dubium, wherein Cnidium dubium especially in 2015 , and Sanguisorba officinalis in 2014.

The differentiation of germination capacity was caused by different share of the dead seeds.

The species differentiated significantly with the dead seeds shares. During the evaluation the very high share of such seeds (above 55\%) was typical for: Cnidium dubium, Sanguisorba officinalis and Scabiosa ochroleuca (Table 5). In 2015 on average twice more dead seeds were noticed than in 2014. In the case of Eryngium planum that difference was equal to ten times, while for Planta- 
TABLE 5. The share of dead seeds depending on species (\%)

\begin{tabular}{|c|c|c|c|c|c|c|}
\hline \multirow{2}{*}{ Species (S) } & \multicolumn{4}{|c|}{ Year of harvest $(\mathrm{Y})$} & \multicolumn{2}{|c|}{$\begin{array}{l}\text { Coefficient of } \\
\text { variation }\end{array}$} \\
\hline & 2014 & 2015 & $\begin{array}{l}L S D_{0.05} \\
(\text { for Y) }\end{array}$ & Mean (S) & 2014 & 2015 \\
\hline $\begin{array}{l}\text { Cnidium dubium (Schkuhr) Thell } \\
\text { Allium angulosum L. }\end{array}$ & $\begin{array}{c}20 \mathrm{a}^{*} \\
1 \mathrm{a}\end{array}$ & $\begin{array}{c}96 f \\
6 a\end{array}$ & $\begin{array}{l}7.4 \\
9.2\end{array}$ & $\begin{array}{c}58.0 \mathrm{~b} \\
3.5 \mathrm{a}\end{array}$ & $\begin{array}{c}20.0 \\
-\end{array}$ & $\begin{array}{c}2.4 \\
88.2\end{array}$ \\
\hline $\begin{array}{l}\text { Sanguisorba officinalis L. } \\
\text { Galium boreale L. }\end{array}$ & $\begin{array}{l}64 \mathrm{~b} \\
10 \mathrm{a} \\
\end{array}$ & $\begin{array}{l}47 \mathrm{~cd} \\
39 \mathrm{~cd}\end{array}$ & $\begin{array}{l}25.7 \\
14.9\end{array}$ & $\begin{array}{l}55.5 \mathrm{~b} \\
24.5 \mathrm{a}\end{array}$ & $\begin{array}{l}20.0 \\
21.6\end{array}$ & $\begin{array}{l}17.1 \\
23.3 \\
\end{array}$ \\
\hline $\begin{array}{l}\text { Achillea millefolium } \mathrm{L} . \\
\text { Plantago lanceolata } \mathrm{L} .\end{array}$ & $\begin{array}{l}15 \mathrm{a} \\
11 \mathrm{a}\end{array}$ & $\begin{array}{c}29 \mathrm{~b} \\
13 \mathrm{ab}\end{array}$ & $\begin{array}{l}13.5 \\
14.2\end{array}$ & $\begin{array}{l}22.0 \mathrm{a} \\
12.0 \mathrm{a}\end{array}$ & $\begin{array}{l}56.8 \\
78.1\end{array}$ & $\begin{array}{r}4.0 \\
24.1\end{array}$ \\
\hline $\begin{array}{l}\text { Eryngium planum } \mathrm{L} . \\
\text { Scabiosa ochroleuca } \mathrm{L} \text {. }\end{array}$ & $\begin{array}{c}5 \mathrm{a} \\
48 \mathrm{~b}\end{array}$ & $\begin{array}{l}51 \mathrm{~cd} \\
62 \mathrm{e}\end{array}$ & $\begin{array}{c}8.9 \\
21.8 \\
\end{array}$ & $\begin{array}{l}28.0 \mathrm{ab} \\
55.0 \mathrm{~b}\end{array}$ & $\begin{array}{l}86.6 \\
16.7 \\
\end{array}$ & $\begin{array}{c}6.0 \\
17.6 \\
\end{array}$ \\
\hline$L S D_{0.05}($ for $\mathrm{S})$ & 21.0 & 18.0 & - & 30.0 & - & - \\
\hline Mean $(\mathrm{Y})$ & 21.7 & 39.1 & - & - & - & - \\
\hline$L S D_{0.05}(\mathrm{Y})$ & \multicolumn{2}{|c|}{9.4} & - & - & - & - \\
\hline
\end{tabular}

* Homogenous groups in columns.

go lanceolata the share of the dead seeds was lowest and similar in two years. It is worth mentioning that for both species the variation coefficient of the dead seeds (harvested in 2014) was high and exceeded $78 \%$.

The fresh ungerminated seeds of four studied species (Table 6), two typical ones for xerothermic grasslands; Achillea millefolium and Sanguisorba officinalis were not found. In the wet habitats the share of that group of the seeds was generally higher than in the drier ones. The highest share of fresh ungerminated seeds was due to Galium boreale (30.5\% on average). Relatively high share of the seeds of that group was shown by the species of Cnidion dubii meadows (about 20\%) It is worth emphasizing that the estimation of the seed germination was made in July next year after seed harvest, since in the period, when the primary dormancy could go by.
The high share of fresh ungerminated seeds may show that the seed dormancy did not pass off yet. It is seemed that the weather conditions in 2015 could impact the faster breaking out of the Cnidium dubium seeds' dormancy.

The abnormal seedlings were the last of the analysed groups of the categories of germination. The investigated species characterized themselves by low share of such seedlings ( $2 \%$ on average). In 2014 abnormal seedlings appeared only in Sanguisorba officinalis (25\%) and Galium boreale (3\%), but in 2015 in all species, most often in Achillea millefolium (12\%).

The hierarchic analyse of the vigour aggregation and four germination capacities allow for singling out two basic groups of species of different level of probability (Fig.). The first one includes the species of relatively little vigour ( $15 \%$ on average) and germination 
TABLE 6. The share of fresh ungerminated seeds depending on the species (\%)

\begin{tabular}{|c|c|c|c|c|c|c|}
\hline \multirow{2}{*}{ Species (S) } & \multicolumn{4}{|c|}{ Year of harvest (Y) } & \multicolumn{2}{|c|}{$\begin{array}{l}\text { Coefficient of } \\
\text { variation }\end{array}$} \\
\hline & 2014 & 2015 & $\begin{array}{l}\mathrm{LSD}_{0.05} \\
\text { (for Y) }\end{array}$ & Mean (S) & 2014 & 2015 \\
\hline Cnidium dubium (Schkuhr) Thell. & $43 d^{*}$ & $0 \mathrm{a}$ & 12.1 & $21.5 \mathrm{bc}$ & 18.6 & 0.0 \\
\hline Allium angulosum $\mathrm{L}$. & $19 \mathrm{bc}$ & $17 \mathrm{~b}$ & 17.4 & $18.0 \mathrm{bc}$ & 53.9 & 24.0 \\
\hline Sanguisorba officinalis L. & 0a & 0a & 0.0 & $0.0 \mathrm{a}$ & - & - \\
\hline Galium boreale L. & $35 \mathrm{~cd}$ & $26 c$ & 16.2 & $30.5 \mathrm{c}$ & 26.6 & 15.6 \\
\hline Achillea millefolium $\mathrm{L}$. & $0 \mathrm{a}$ & $0 \mathrm{a}$ & 0.0 & $0.0 \mathrm{a}$ & - & - \\
\hline Plantago lanceolata $\mathrm{L}$. & $12 \mathrm{ab}$ & $16 b$ & 6.4 & $14.0 \mathrm{ab}$ & 0.0 & 25.0 \\
\hline Eryngium planum $\mathrm{L}$. & $0.0 \mathrm{a}$ & $0.0 \mathrm{a}$ & 0.0 & $0.0 \mathrm{a}$ & - & - \\
\hline Scabiosa ochroleuca & $0.0 \mathrm{a}$ & $0.0 \mathrm{a}$ & 0.0 & $0.0 \mathrm{a}$ & - & - \\
\hline$L S D_{0.05}($ for $\mathrm{S})$ & 17.0 & 4.4 & - & 16.5 & - & - \\
\hline Mean (Y) & 13.5 & 7.4 & - & - & - & - \\
\hline$L S D_{0.05}(Y)$ & 5.2 & - & - & - & - & - \\
\hline
\end{tabular}

* Homogenous groups in columns.

\section{Dendrogram}

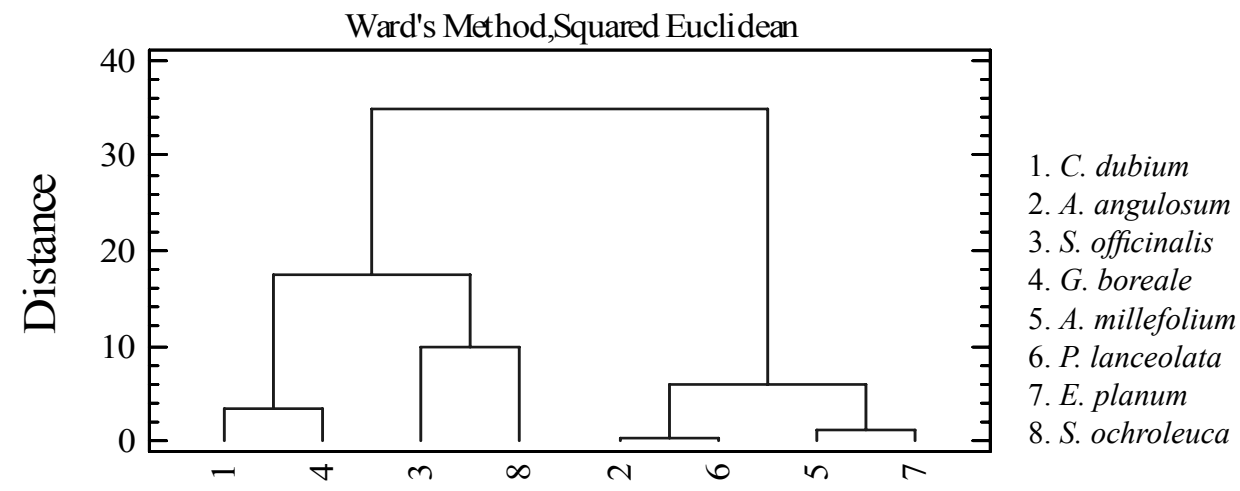

FIGURE. The dendrogram and the division of the tested species of natural-valuable meadow habitats into groups of the similar parameters of the seed material values (Euclidean distance)

capacity (34\% on average) and the high share of dead seeds ( $48 \%$ on average). That group includes the species typical for wet habitats (Cnidium dubium, Galium boreale, Sanguisorba officinalis) and Scabiosa ochroleuca. Cnidium dubium and Galium boreale characterised themselves by relatively high share of fresh ungerminated seeds ( $26 \%$ on average), in the distinction to other species of that group.

In the second group the species of the high vigour (59\% on average) and germination capacity ( $73 \%$ on average), as 
well as low share of dead seeds $(16 \%$ on average) were put: Allium angulosum, Plantago lanceolata, Achillea millefolium and Eryngium planum. Two first consisted of the separate sub-group due to very low share of dead seeds ( $8 \%$ on average) and the presence of fresh ungerminated seeds ( $16 \%$ on average).

\section{CONCLUSIONS}

- The species of following types of the habitats: Cnidion dubii (6440) and Molinion (6410) demand the pre-chilling to break the seed dormancy, but the species of Arrhenatherion (6510) and Festuco-Brometea (6210) do not.

- The high values of the seed material (high vigour and germination capacity, low share of dead seeds) were typical for Allium angulosum, Plantago lanceolata, Achillea millefolium and Eryngium planum.

- The weather conditions during reproductive development and seed ripening are of high importance for the seed material value. The extreme drought in 2015 caused decreasing in the germination capacity and increasing in the share of dead seeds.

- The preliminary studies, presented in this paper, show that most difficult to restore may be Cnidion and Molinion meadows because of the necessity of breaking the seed dormancy, they are also more sensitive to unfavourable weather conditions in the seed ripening stage, and their seeds in the soil are transient or short-term persistent.

\section{REFERENCES}

BASKIN J., BASKIN C. 2004. A classification system for seed dormancy. Seed Science Research 14, 1-16.

ELLIS R., HONG T., ROBERTS E. 1985: Handbook of seed technology for genebanks. Volume II. Compendium of specific germination information and test recommendations. International Board for Plant Genetic Resources. Handbooks for Genebanks, 3, Rome.

Council Directive 92/43/EEC of 21 May 1992 on the conservation of natural habitats and of wild fauna and flora (Dz. U. L $206 \mathrm{z}$ dnia 22.7.1992, z późn. zm.).

Directive 2009/147/EC of the European Parliament and of the Council of 30 November 2009 on the conservation of wild birds (Dz. U. L 20 z 26.1.2010, z późn. zm.).

Directive 2004/35/CE of the European Parliament and of the Council of 21 April 2004 on environmental liability with regard to the prevention and remedying of environmental damage.

EU 2010: EU Biodiversity Action Plan: 2010 Assessment European Union.

GIOŚ 2012: Monitoring gatunków i siedlisk przyrodniczych ze szczególnym uwzględnieniem specjalnych obszarów ochrony siedlisk Natura 2000. Podsumowania wyników monitoringu siedlisk przyrodniczych w latach 2009-2011. Warszawa.

GUS 2015: Wyniki produkcji roślinnej w 2014 r. Informacje i opracowania statystyczne. Warszawa.

GUS 2016: Wyniki produkcji roślinnej w 2015 r. Informacje i opracowania statystyczne. Warszawa.

HASLGRÜBLER P., KRAUTZER B., BLASCHKA A., GRAISS W., PÖTSCH E.M. 2013. Quality characteristics of seed material from selected species of a nutrient poor Arrhenatherion community. Grassland Science in Europe 18, 442-444.

HASLGRÜBLER P., KRAUTZER B., GRAISS W. 2011. Germination capacity of threshed material from an Arrhenatherion meadow. In: Grassland farming and land management systems in mountainous regions. Proceedings of the 16th Symposium of the European Grassland Federation, Gumpenstein, Austria, 29th-31st August, 2011, 523-525. 
HÖLZEL N., OTTE A. 2004: Ecological significance of seed germination characteristics in flood-meadow species. Flora 199, 12-24.

ISTA 2015: Międzynarodowe przepisy oceny nasion 2015, polska wersja wydania 2015, IHAR-PIB ZNiN, 1-766.

JANICKA M. 2015: Możliwości odtwarzania bogatych florystycznie półnaturalnych łąk. In: Gospodarowanie w dolinach rzecznych na obszarach Natura 2000 - problemy działalności inwestycyjnej. B. Pawluśkiewicz (Ed.). Wyd. SGGW, Warszawa, 97-112.

KRAUTZER B., HASLGRÜBLER P., BLASCHKA A., GRAISS W., PÖTSCH E.M. 2013: Quality characteristics of seed material harvested from Molinion litter meadow. Grassland Science in Europe 18, 487-489.

MIREK Z., PIĘKOŚ-MIRKOWA H., ZAJĄC A., ZAJĄC M. 1995: Vascular plants of Poland - a checklist. Polish Bot. Stud. Guideb. Ser. 15: 1-303.

Projekt FlorNatur ROBiA 2014: Ocena stanu populacji oraz ochrona ex situ wybranych dziko rosnących gatunków roślin rzadkich i zagrożonych na terenie Polski. Rada Ogrodów Botanicznych i Arboretów w Polsce, Mikołów.

PUCHALSKI J., NIEMCZYK M., WALEROWSKI P., PODYMA W., KAPLER A. 2014: Seed banking of Polish endangered plants - the FlorNatur Project. Biodiversity: Research and Conservation 34, 65-72.

Rozporządzenie Ministra Środowiska z dnia 9 października 2014 r. w sprawie ochrony gatunkowej roślin. Dz.U. 2014, poz. 1409.

SCOTTON M., KIRMER A., KRAUTZER B. (Ed.) 2012: Practical handbook for seed harvest and ecological restoration of species-rich grasslands. CLEUP, Padova, Italy, 1-116.

SPECHT C.E., KELLER E.R.J. 1997: Temperature requirements for seed germination in species of the genus Allium L. Genetic Resources and Crop Evolution, 44, 509-517.

THOMPSON K., BAKKER J.P., BEKKER R.M. 1997: The soil seedbanks of North West Europe: methodology, density and longevity. Cambridge University Press, Cambridge.

ZARZYCKI K., SZELĄG Z. 2006: Red list of the vascular plants in Poland. Czerwona lista roślin naczyniowych w Polsce. In: Red list of plants and fungi in Poland. Czerwona lista ro- ślin i grzybów Polski. Z. Mirek, K. Zarzycki, W. Wojewoda, Z. Szeląg (Eds). Wyd. Instytut Botaniki im. W. Szafera, Polska Akademia Nauk, Kraków.

Streszczenie: Ocena materiatu nasiennego kilku dziko rosnqcych gatunków dwuliściennych, cennych przyrodniczo siedlisk takowych. Odtworzenie składu gatunkowego zbiorowisk łąkowych siedlisk przyrodniczych, w glebie których pozostało mało diaspor roślin łąkowych, wiąże się $\mathrm{z}$ wprowadzeniem nasion typowych gatunków. Skuteczność tego zabiegu wymaga dokładnego poznania biologii kiełkowania poszczególnych gatunków. Badaniami objęto osiem gatunków roślin, czterech nieleśnych siedlisk przyrodniczych występujących w dolinach rzek, tj. łąk selernicowych (6440), zmiennowilgotnych łąk trzęślicowych (6410), nizinnych ekstensywnie użytkowanych łąk świeżych (6510) oraz muraw kserotermicznych (6210). Diaspory zebrano w latach 2014-2015 na łąkach Obszaru Specjalnej Ochrony Siedlisk Doliny Dolnej Pilicy (PLH 140016), w pobliżu miejscowości Mniszew. Dokonano oceny zdolności kiełkowania nasion w warunkach laboratoryjnych. Stwierdzono, że badane gatunki łąk selernicowych i trzęślicowych do przerwania stanu spoczynku nasion wymagają wcześniejszego chłodzenia, natomiast łąk świeżych oraz muraw kserotermicznych nie wymagają tego zabiegu. Dużym wigorem i znaczną zdolnością kiełkowania, a małym udziałem nasion martwych odznaczały się Allium angulosum, Plantago lanceolata, Achillea millefolium i Eryngium planum. $\mathrm{Na}$ wartość materiału nasiennego duży wpływ miały warunki pogodowe w okresie rozwoju generatywnego. Katastrofalna susza w 2015 roku spowodowała zmniejszenie zdolności kiełkowania i zwiększenie udziału nasion martwych. Wstępne wyniki badań przedstawione w tej pracy wskazują, że najtrudniejsze do odtworzenia mogą być łąki selernicowe i trzęślicowe, ze względu na konieczność przełamania spoczynku nasion, ponadto są one bardziej wrażliwe na niesprzyjające warunki pogodowe $\mathrm{w}$ okresie dojrzewania nasion. Przeprowadzone badania mają znaczenie praktyczne dla prac związanych ze zwiększaniem różnorodności florystycznej zagrożonych zbiorowisk i odtwarzaniem zniszczonych siedlisk łąkowych. 
MS received June 2016

Authors' addresses:

Maria Janicka

Katedra Agronomii

Wydział Rolnictwa i Biologii SGGW

ul. Nowoursynowska 159, 02-776 Warszawa

Poland

e-mail: maria_janicka@sggw.pl

Bogumiła Pawluśkiewicz

Katedra Kształtowania Środowiska

Wydział Budownictwa i Inżynierii Środowiska

SGGW

ul. Nowoursynowska 159, 02-776 Warszawa

Poland

Elżbieta Małuszyńska, Anna Szydłowska

Zakład Nasiennictwa i Nasionoznawstwa

Instytut Hodowli i Aklimatyzacji Roślin

- Państwowy Instytut Badawczy

Radzików, 05-870 Błonie

Poland 